\title{
Ebelik öğrencilerinin normal vajinal doğum yapma konusundaki görüșleri
}

\author{
Opinions of midwifery students about normal vaginal birth
}

\author{
Saadet Gonca Mavi Aydoğdu®, Betül Uzun®, Ülkü Özsoy®
}

\section{öz}

AMAÇ: Bu çalşsma, ebelik öğrencilerinin normal vajinal doğum konusundaki görüşlerini ve doğum tercihlerinin nedenlerini saptamak amacyyla yapildi.

GEREÇ VE YÖNTEM: Tanımlayıcı nitelikteki araştırma, 2017-2018 öğretim yılı/bahar yarıyılında Amasya Üniversitesi Sağlık Bilimleri Fakültesi ebelik bölümü öğrencileriyle yürütüldü $(\mathrm{N}=88)$. Veriler araştırmacılar tarafindan hazırlanan soru formu kullanılarak 05-09 Mart 2018 tarihleri arasında toplandi, SPSS 20 paket programında analiz edildi.

BULGULAR: Araştırmaya katılan öğrencilerin yaş ortalaması $20,23 \pm 2,20$ 'dir. Doğum dersi almayan öğrencilerin $\% 78$ 'i, doğum dersi alan öğrencilerin $\% 84,2$ 'si normal vajinal doğumu tercih ettiklerini belirtmektedirler. Doğum dersi alan öğrencilerin \%92,1’i doğum dersinin doğum tercihlerini etkilediğini, doğum dersi almanın doğum tercihlerini etkilediğini belirten öğrencilerin ise $\% 91,4$ ü tercihlerini olumlu yönde etkilediğini belirtmektedirler.

SONUÇ: Çalışmamızda, doğum dersi alan öğrencilerin çoğu normal doğumu tercih etmektedirler. Öğrencilerin normal doğum konusunda olumlu tutum geliştirebilmesi, bu konudaki eksikliklerinin giderilmesi ve karar verme becerilerinin güçlendirilmesiyle mümkündür.

Anahtar Kelimeler: Doğum tercihi, normal vajinal doğum, öğrenci

\section{Gíriș}

Normal vajinal doğum mümkün olduğunca müdahale edilmeden gerçekleştirilen, kadın vücudunun fizyolojik yapısına en uygun doğum şeklidir. ${ }^{[1-3]}$ Normal vajinal doğum yapan kadın hastanede daha kısa süre kalır, erken dönemde ayağa kalkar ve anne-bebek arasındaki etkileşim en kısa sürede başlar. ${ }^{[4-6]}$ Sezaryen doğum ise normal vajinal doğumun mümkün olmadığı ya da anne/bebek

Amasya Üniversitesi Sağlık Bilimleri Fakültesi, Ebelik Bölümü, Amasya, Türkiye

\section{Yazısma Adresi/ Correspondence:}

Öğr. Gör. Saadet Gonca Mavi Aydoğdu

Amasya Üniversitesi Sağlık Bilimleri Fakültesi, İpekköy Yerleşkesi 05100, Amasya,

Türkiye

Tel. +905536356093

E-mail: goncamavi38@gmail.com

Geliş/ Received: $\quad 11.04 .2018$

Kabul/ Accepted: 21.04 .2018

\section{ABSTRACT}

OBJECTIVES: This study was conducted to determine the opinions of midwives on normal vaginal birth and the causes of birth preferences.

MARERIAL AND METHODS: Descriptive research was carried out in the midwifery department of the Faculty of Health Sciences of the University of Amasya ( $\mathrm{N}=88$ ) in the 2017-2018 academic year/spring semester. The data were collected between 05-09 March 2018 using the questionnaire prepared by the researchers and analyzed in the SPSS 20 package program.

RESULTS: The average age of the students participating in the survey is $20.23 \pm 2.20$. In our study, $78 \%$ of the students who did not take birth lessons and $84.2 \%$ of students who took birth lessons stated that they preferred normal vaginal birth. Birth lessons affected the birth preferences of $92.1 \%$ of the students who took the lesson, and $91.4 \%$ of the students who stated that taking the birth lesson affected the birth preferences also stated that the lesson affected the choice positively.

CONCLUSION: In our study, it was found that the majority of students who took birth lessons preferred normal birth. The ability of students to develop positive attitudes towards normal birth is possible through the elimination of deficiencies, and strengthening of decision-making skills. Keywords: Birth preference, normal vaginal birth, student

açısından riskli olduğu durumlarda uygulanan cerrahi girişimdir. ${ }^{[7-9]}$ Tıbbi bir gerekçe olmadan isteğe bağlı uygulanan sezaryen, anne ve bebek sağlığı üzerinde birçok komplikasyona yol açmaktadır. ${ }^{[10,11]}$ Buna rağmen yapılan çalışmalar tüm dünyada olduğu gibi ülkemizde de sezaryen oranlarının giderek arttığını göstermektedir. ${ }^{[3,12-14]}$ Artan sezaryen oranlarının önüne geçmek için gebelerin sezaryen tercihlerinde etkili olan faktörlerin bilinmesi gerekmektedir. ${ }^{[15,16]}$ Normal vajinal doğuma ilişkin yaşanılan korkunun gebelerin sezaryen tercihlerinde etkili olduğu bilinmektedir. ${ }^{[2,3,9,16-18]}$ Ayrıca kadınların ileri yaşlarda ve az sayıda çocuk sahibi olmak istemeleri, sezaryen ile doğumun daha güvenli olduğunu düşünmeleri, sosyo-ekonomik düzeyin yüksek olması, doğum ağrısı çekmek istememeleri, yazılı-görsel basında doğumun korkutucu bir şekilde anlatılması ve normal vajinal doğumla ilgili olumsuz deneyimleri de sezaryen ile doğumu tercih etme nedenlerindendir. ${ }^{[2,3,9,13,19-21]}$ 
Ebeler, kadınların doğum şekline karar verebilmelerinde iyi bir antenatal izlem ve danışmanlık hizmetleri ile kadınların normal vajinal doğuma yönelik korku ve anksiyetelerini azaltmalı, onları doğum eylemine hazırlamalı ve olumlu doğum deneyimi edinmelerini sağlamalıdırlar. [2,3,9,18,22-24] Ebelerin nitelikli bir danışmanlık hizmeti verebilmesi için önce doğum şekline yönelik doğru ve yeterli bilgiye sahip olmaları gerekmektedir. ${ }^{[3,18]} \mathrm{Bu}$ amaçla, henüz yolun başında olan ebelik bölümü öğrencilerinin doğum dersini almadan önce ve aldıktan sonra doğum şekline ilişkin düşüncelerinin bilinmesi önemlidir. ${ }^{[25]} \mathrm{Bu}$ doğrultuda yaptığımız çalışmada; ebelik öğrencilerinin normal vajinal doğum konusundaki görüşlerini belirlemeyi, doğum şekli tercihlerinin nedenlerini saptamayı ve normal vajinal doğumu teşvik etmeyi amaçlamaktayız.

\section{GEREÇ VE YÖNTEM}

\section{Araștırmanın tipi}

$\mathrm{Bu}$ çalışma, ebelik öğrencilerinin normal vajinal doğum konusundaki görüşlerini ve doğum tercihlerinin nedenlerini inceleyen tanımlayıcı bir araştırmadır.

\section{Araștırmanın evren ve örneklemi}

Araştırmanın evrenini 2017-2018 öğretim yılı/bahar yarıyılında Amasya Üniversitesi Sağlık Bilimleri Fakültesi ebelik bölümünde öğrenimlerini sürdüren 88 öğrenci oluşturmuştur. Araştırmada örneklem seçimine gidilmemiş, 05-09 Mart 2018 tarihleri arasında bütün ebelik öğrencilerine ulaşılmıştır.

\section{Veri toplama araçları}

Anket formu, öğrencilerin sosyo-demografik özellikleri ile normal vajinal doğuma ilişkin görüşlerini değerlendiren iki formdan oluşmaktadır. Soru formları araştırmacılar tarafından literatürden yararlanılarak [2,3,6,9,19,26] oluşturulmuştur.

*Kişisel Bilgi Formu: Bu form, ebelik öğrencilerinin bazı sosyo-demografik özelliklerini belirlemek amacıyla hazırlanmıştır. Formda araştırmaya katılacak öğrencilerin yaşı, sınıfı, medeni durumu, anne-baba mesleği ve eğitim durumu, ekonomik durumu, aile tipi ve doğum şekli tercihlerine ilişkin toplam 15 soru yer almaktadır.

\section{**Öğrencilerin Normal Vajinal Doğuma İlişkin} Görüşlerini Değerlendirme Formu: Bu form, ebelik öğrencilerinin normal vajinal doğuma ilişkin görüşlerini tanımlamaya yönelik hazırlanan 11 sorudan oluşmaktadır.

\section{Verilerin toplanması}

Araştırmanın verileri 2017-2018 öğretim yılı/bahar yariyılında 05-09 Mart 2018 tarihlerinde, derslere devam eden ve çalışmaya katılmayı kabul eden öğrencilerden toplanmıştır. Soru formu dağıtılmadan önce öğrencilere araştırmanın amacı açıklanmış, kişisel bilgilerinin gizli tutulacağına dair gerekli açıklama yapılmış ve onam formu okutularak sözel onamları alınmıştır. Veri toplama formları sınıf ortamında 10-15 dakikalık sürelerde doldurulmuştur.

\section{Verilerin değerlendirilmesi}

$\mathrm{Bu}$ çalışmada elde edilen veriler SPSS 20 paket programı ile analiz edilmiştir. Değişkenlerin normal dağılımdan gelme durumları araştırılırken Kolmogorov-Smirnov testinden yararlanılmıştır. Gruplar arasındaki farklılıklar incelenirken değişkenlerin normal dağılımdan gelmemesi durumunda Mann-Whitney-U ve Kruskal-Wallis-H testlerinden yararlanılmıştır. Nominal değişkenlerin grupları arasındaki ilişkiler incelenirken ki-kare analizi uygulanmıştır. RxC tablolarda gözelerdeki beklenen değerlerin yeterli hacme sahip olmaması durumunda Monte Carlo simülasyonu yardımıyla Fisher's Exact testi ve Pearson ki-kare analizi uygulanmıştır. Normal dağılımdan gelmeyen değişkenler arasındaki ilişkiler incelenirken Spearman's korelasyon katsayısından yararlanılmıştır.

\section{Araștırmanın sınırlılıkları}

Araştırmanın küçük bir örneklem grubunda yapılması araştırmanın sınırlılığı olarak değerlendirilmektedir.

\section{Araștırmanın etik yönü}

Çalışmanın uygulanabilmesi için gerekli etik kurul ve kurum izni alınmıştır. Araştırmaya katılmayı gönüllülük esasına göre kabul eden öğrenciler, araştırmanın amacı ve uygulanması hakkında bilgilendirilmiş ve sözel onam alınmıştır.

\section{BULGULAR}

Araştırmaya katılan öğrencilerin yaş ortalaması $20,23 \pm 2,20$ olup, \%34,1'i 1. sınıf ve \%96,6’sı bekârdır. Öğrencilerin $\% 45,5$ 'i yaşamının çoğunu ilde geçirmiştir. Öğrencilerin \%67'sinin annesi, \%37,5'inin babası ilkokul mezunudur. Öğrencilerin \%55,7'sinin babası serbest meslekle uğraşırken, \%87,5'inin annesi ev hanımıdır. Öğrencilerin \%77,3'ü çekirdek ailede yaşadığını, \%67'si gelirinin giderine eşit olduğunu belirtmiştir (Tablo 1).

Tablo 2'de öğrencilerin doğum dersi alma durumlarına göre doğum şekli tercihlerinin dağılımına yer verilmiştir. 
Tablo 1. Öğrencilerin tanıtıcı özelliklerinin dağılımı

\begin{tabular}{|c|c|c|c|}
\hline \multicolumn{2}{|l|}{ Tanıticı Özellikler } & Sayı & $\%$ \\
\hline \multicolumn{2}{|l|}{ Yaş (Ortalama \pm SS) } & \multicolumn{2}{|c|}{$20,23 \pm 2,20$} \\
\hline \multirow[t]{5}{*}{ Sinıfi } & 1. Sinıf & 30 & 34,1 \\
\hline & 2. Sinıf & 20 & 22,7 \\
\hline & 3. Sinıf & 19 & 21,6 \\
\hline & 4. Sinıf & 19 & 21,6 \\
\hline & Toplam & 88 & 100,0 \\
\hline \multirow[t]{3}{*}{ Medeni Durumu } & Evli & 3 & 3,4 \\
\hline & Bekâr & 85 & 96,6 \\
\hline & Toplam & 88 & 100,0 \\
\hline \multirow{4}{*}{$\begin{array}{l}\text { Yaşamının Çoğun- } \\
\text { luğunu Geçirdiği Yer }\end{array}$} & il & 40 & 45,5 \\
\hline & İlçe & 29 & 33,0 \\
\hline & Köy/Kasaba & 19 & 21,6 \\
\hline & Toplam & 88 & 100,0 \\
\hline \multirow[t]{4}{*}{ Anne Eğitim Durumu } & İlköğretim ve Alt & 59 & 67,0 \\
\hline & Ortaöğretim & 15 & 17,0 \\
\hline & Lise ve Üstü & 14 & 15,9 \\
\hline & Toplam & 88 & 100,0 \\
\hline \multirow[t]{4}{*}{ Baba Eğitim Durumu } & İlköğretim ve Altı & 33 & 37,5 \\
\hline & Ortaöğretim & 26 & 29,5 \\
\hline & Lise ve Üstü & 29 & 33,0 \\
\hline & Toplam & 88 & 100,0 \\
\hline \multirow[t]{6}{*}{ Annenin Mesleği } & Ev Hanımı & 77 & 87,5 \\
\hline & İşçi & 6 & 6,8 \\
\hline & Memur & 1 & 1,1 \\
\hline & Serbest Meslek & 4 & 4,5 \\
\hline & Toplam & 88 & 100,0 \\
\hline & İşçi & 27 & 30,7 \\
\hline \multirow{4}{*}{ Babanın Mesleği } & Memur & 12 & 13,6 \\
\hline & Serbest Meslek & 49 & 55,7 \\
\hline & Toplam & 88 & 100,0 \\
\hline & Çekirdek Aile & 68 & 77,3 \\
\hline \multirow[t]{3}{*}{ Aile Yapısı } & Geniş Aile & 20 & 22,7 \\
\hline & Toplam & 88 & 100,0 \\
\hline & Gelir Giderden Az & 18 & 20,5 \\
\hline \multirow{3}{*}{ Ekonomik Durumu } & Gelir Gidere Eşit & 59 & 67,0 \\
\hline & Gelir Giderden Fazla & 11 & 12,5 \\
\hline & Toplam & 88 & 100,0 \\
\hline
\end{tabular}

Doğum dersi almayan (1. ve 2. sınıf) öğrencilerin \%78'i, doğum dersi alan (3. ve 4. sınıf) öğrencilerin \%84,2'si normal vajinal yolla doğumu tercih ettiklerini belirtmiştir. Doğum dersi almış olmanın öğrencilerin tercihlerini etkileme durumu incelendiğinde, doğum dersi alanların normal vajinal doğumu daha fazla tercih ettikleri görülmüştür $(92,1)$. Doğum dersi almış olmanın doğum şekli tercihini etkilediğini belirten öğrencilerin \%91,4’ü, dersin tercihlerini olumlu yönde etkilediğini belirtmişlerdir. Öğrencilerin
Tablo 2. Öğrencilerin doğum dersi alma durumlarına göre doğum şekli tercihlerinin dağılımı

\begin{tabular}{|c|c|c|c|c|c|c|}
\hline & \multicolumn{6}{|c|}{ Gruplar } \\
\hline & \multicolumn{2}{|c|}{$\begin{array}{l}\text { Doğum Dersi } \\
\text { Almayanlar }\end{array}$} & \multicolumn{2}{|c|}{$\begin{array}{c}\text { Doğum } \\
\text { Dersi Alanlar }\end{array}$} & \multicolumn{2}{|c|}{ Toplam } \\
\hline & $\mathrm{n}$ & $\%$ & $\mathrm{n}$ & $\%$ & $\mathrm{n}$ & $\%$ \\
\hline \multicolumn{7}{|l|}{ Doğum Şekli Tercihi } \\
\hline $\begin{array}{l}\text { Normal Vajinal } \\
\text { Doğum }\end{array}$ & 39 & 78,0 & 32 & 84,2 & 71 & 80,7 \\
\hline $\begin{array}{l}\text { Lokal Anestezi İle } \\
\text { Vajinal Doğum }\end{array}$ & 3 & 6,0 & 3 & 7,9 & 6 & 6,8 \\
\hline Sezaryen İle Doğum & 2 & 4,0 & 1 & 2,6 & 3 & 3,4 \\
\hline Kararsız & 6 & 12,0 & 2 & 5,3 & 8 & 9,1 \\
\hline Toplam & 50 & 100,0 & 38 & 100,0 & 88 & 100,0 \\
\hline \multicolumn{7}{|l|}{$\begin{array}{l}\text { Doğum Dersinin } \\
\text { Doğum Şekli Terci- } \\
\text { hine Etkisi }\end{array}$} \\
\hline Evet & 0 & 0,0 & 35 & 92,1 & 35 & 92,1 \\
\hline Hayır & 0 & 0,0 & 3 & 7,9 & 3 & 7,9 \\
\hline Toplam & 0 & 0,0 & 38 & 100,0 & 38 & 100,0 \\
\hline $\begin{array}{l}\text { Doğum Dersinin } \\
\text { Doğum Şekli Tercihi- } \\
\text { ni Nasıl Etkilediği } \\
\text { Olumlu }\end{array}$ & 0 & 0,0 & 32 & 91,4 & 32 & 91,4 \\
\hline Olumsuz & 0 & 0,0 & 3 & 8,6 & 3 & 8,6 \\
\hline Toplam & 0 & 0,0 & 35 & 100,0 & 35 & 100,0 \\
\hline
\end{tabular}

doğum dersi alma durumları ile normal vajinal doğum tercihleri $(\mathrm{p}=0,647)$ arasında istatistiksel olarak anlamlı bir farklılık bulunmamakla birlikte, doğum dersi almış olmanın öğrencilerin tercihlerini etkilediğini söylenebilir.

Lokal anestezi ile vajinal doğum veya sezaryen ile doğum yapmak isteyen öğrencilerin normal vajinal doğum yapmak istememe nedenleri incelendiğinde; doğum korkusunun $(\% 77,8)$, doğum ağrısı ile baş edemeyeceği kaygısının $(\% 77,8)$, estetik kaygıların $(\% 55,6)$, kontrolünü kaybetme endişesinin $(\% 33,3)$, sağlık personelinin bilgi eksikliğinin $(\% 33,3)$, doğum sonrası cinsel sorunlar yaşama kaygısının (\%33,3), sağlık personelinin davranış ve tutumlarının $(\% 22,2)$, çevredekilerin kötü deneyimlerini paylaşmasının $(\% 22,2)$ ve doğum konusunda bilgi eksikliğinin $(\% 11,1)$ etkili olduğu görülmüştür.

Öğrencilerin gelecekte sahip olmak istedikleri çocuk sayısı $2,77 \pm 0,99$ 'dur. Öğrencilerin normal vajinal doğum tercihleri ile sahip olmak istedikleri çocuk sayısı arasında istatistiksel olarak anlamlı bir ilişki bulunmamakla birlikte, normal vajinal yolla doğum yapmak isteyenlerin daha fazla sayıda çocuk sahibi olmak istedikleri görülmüştür $(\mathrm{p}=0,781)$. 
Öğrencilerin kardeş sayısı 3,08 $\pm 1,76$ 'dır. Öğrencilerin kardeş sayısı ile normal vajinal doğum tercihleri arasında istatistiksel olarak anlamlı bir farklılık bulunmamakla birlikte, normal vajinal yolla doğum yapmak isteyenlerin kardeş sayılarının fazla olduğu bulunmuştur $(\mathrm{p}=0,075)$.

Tablo 3’te öğrencilerin normal vajinal doğuma ilişkin görüşlerine yer verilmiş̧ir. Öğrencilerin doğum dersi alma durumları ile "İlk doğumun şekli, diğer doğumların şeklini belirler." önermesi arasında istatistiksel olarak anlamlı bir ilişki bulunmuştur ( $\mathrm{p}=0,01)$. Doğum dersi alanlarda katılma oranı anlamlı derecede düşük görülmektedir $(\% 26,3)$.
Öğrencilerin doğum dersi alma durumları ile "Normal doğumdan sonra anne-bebek etkileşimi erken dönemde başlar." önermesi arasında istatistiksel olarak anlamlı bir ilişki bulunmuştur $(\mathrm{p}=0,014)$. Doğum dersi alanların \%100'ü bu önermeye katılmıştır. Öğrencilerin doğum dersi alma durumları ile "Sezaryen doğumun komplikasyonları daha fazladır." önermesi arasında istatistiksel olarak anlamlı bir ilişki bulunmuştur $(\mathrm{p}=0,025)$. Doğum dersi alanların \%97,4’ü bu önermeye katılmıştır. Öğrencilerin doğum dersi alma durumları ile "Normal doğumdan sonra kadınlar kendini daha çabuk toparlar.” önermesi $(\mathrm{p}=0,123)$ arasında

Tablo 3. Öğrencilerin doğum dersi alma durumlarına göre önermelere verdikleri yanıtların karşılaştırılması

\begin{tabular}{|c|c|c|c|c|c|c|c|c|c|}
\hline \multirow{3}{*}{ Önermeler } & \multicolumn{9}{|c|}{ Gruplar } \\
\hline & & \multicolumn{2}{|c|}{$\begin{array}{l}\text { Doğum Dersi } \\
\text { Almayanlar }\end{array}$} & \multicolumn{2}{|c|}{$\begin{array}{l}\text { Doğum Dersi } \\
\text { Alanlar }\end{array}$} & \multicolumn{2}{|c|}{ Toplam } & \multicolumn{2}{|c|}{ Ki-Kare Analizi } \\
\hline & & $\mathrm{n}$ & $\%$ & $n$ & $\%$ & $\mathrm{n}$ & $\%$ & Ki-Kare & $\mathrm{P}$ \\
\hline \multirow[t]{3}{*}{ Normal doğum doğal bir süreçtir. } & Katilıyorum & 49 & 98,0 & 38 & 100,0 & 87 & 98,9 & & \\
\hline & Katilmıyorum & 0 & 0,0 & 0 & 0,0 & 0 & 0,0 & $\mathrm{~F}$ & 0,568 \\
\hline & Kararsızım & 1 & 2,0 & 0 & 0,0 & 1 & 1,1 & & \\
\hline \multirow{3}{*}{$\begin{array}{l}\text { İlk doğumun şekli diğer doğumların şeklini } \\
\text { belirler. }\end{array}$} & Katilıyorum & 31 & 62,0 & 10 & 26,3 & 41 & 46,6 & & \\
\hline & Katılmıyorum & 11 & 22,0 & 22 & 57,9 & 33 & 37,5 & 13,6 & 0,01 \\
\hline & Kararsızım & 8 & 16,0 & 6 & 15,8 & 14 & 15,9 & & \\
\hline \multirow{3}{*}{$\begin{array}{l}\text { Normal doğum sezaryen doğuma göre daha } \\
\text { kolaydır. }\end{array}$} & Katılıyorum & 28 & 56,0 & 26 & 68,4 & 54 & 61,4 & & \\
\hline & Katılmıyorum & 7 & 14,0 & 4 & 10,5 & 11 & 12,5 & 1,4 & 0,491 \\
\hline & Kararsızım & 15 & 30,0 & 8 & 21,1 & 23 & 26,1 & & \\
\hline \multirow{3}{*}{$\begin{array}{l}\text { Normal doğum yapan kadınlar sezaryen } \\
\text { doğuma göre kötü bir deneyim yaşarlar. }\end{array}$} & Kattlıyorum & 5 & 10,0 & 4 & 10,5 & 9 & 10,2 & & \\
\hline & Katilmıyorum & 38 & 76,0 & 24 & 63,2 & 62 & 70,5 & 2,2 & 0,334 \\
\hline & Kararsızım & 7 & 14,0 & 10 & 26,3 & 17 & 19,3 & & \\
\hline \multirow{3}{*}{$\begin{array}{l}\text { Normal doğumdan sonra kadınlar kendini daha } \\
\text { çabuk toparlar. }\end{array}$} & Katılıyorum & 45 & 90,0 & 38 & 100,0 & 83 & 94,3 & & \\
\hline & Katılmıyorum & 1 & 2,0 & 0 & 0,0 & 1 & 1,1 & $*$ & 0,123 \\
\hline & Kararsızım & 4 & 8,0 & 0 & 0,0 & 4 & 4,5 & & \\
\hline \multirow[t]{3}{*}{ Normal doğumdan sonra cinsel hayat bozulur. } & Kattlıyorum & 2 & 4,0 & 2 & 5,3 & 4 & 4,5 & & \\
\hline & Katılmıyorum & 33 & 66,0 & 29 & 76,3 & 62 & 70,5 & $*$ & 0,531 \\
\hline & Kararsızım & 15 & 30,0 & 7 & 18,4 & 22 & 25,0 & & \\
\hline \multirow{3}{*}{$\begin{array}{l}\text { Normal doğumdan sonra anne-bebek } \\
\text { etkileşimi erken dönemde başlar. }\end{array}$} & Katilıyorum & 41 & 82,0 & 38 & 100,0 & 79 & 89,8 & & \\
\hline & Katilmıyorum & 3 & 6,0 & 0 & 0,0 & 3 & 3,4 & $*$ & 0,014 \\
\hline & Kararsızım & 6 & 12,0 & 0 & 0,0 & 6 & 6,8 & & \\
\hline \multirow[t]{3}{*}{ Sezaryen doğum daha ağrısızdır. } & Katilıyorum & 8 & 16,0 & 1 & 2,6 & 9 & 10,2 & & \\
\hline & Katılmıyorum & 35 & 70,0 & 34 & 89,5 & 69 & 78,4 & $*$ & 0,058 \\
\hline & Kararsızım & 7 & 14,0 & 3 & 7,9 & 10 & 11,4 & & \\
\hline \multirow{3}{*}{$\begin{array}{l}\text { Sezaryen doğumun komplikasyonları daha } \\
\text { fazladır. }\end{array}$} & Katilıyorum & 39 & 78,0 & 37 & 97,4 & 76 & 86,4 & & \\
\hline & Katılmıyorum & 2 & 4,0 & 0 & 0,0 & 2 & 2,3 & $*$ & 0,025 \\
\hline & Kararsızım & 9 & 18,0 & 1 & 2,6 & 10 & 11,4 & & \\
\hline \multirow{3}{*}{$\begin{array}{l}\text { Sezaryen doğum anne ve bebek sağlığı için } \\
\text { daha güvenlidir. }\end{array}$} & Katilıyorum & 2 & 4,0 & 0 & 0,0 & 2 & 2,3 & & \\
\hline & Katılmıyorum & 42 & 84,0 & 36 & 94,7 & 78 & 88,6 & $*$ & 0,286 \\
\hline & Kararsızım & 6 & 12,0 & 2 & 5,3 & 8 & 9,1 & & \\
\hline \multirow{3}{*}{$\begin{array}{l}\text { Doğum öncesi destek ve bilgilendirme } \\
\text { kadınların doğum şekli tercihinde etkili ve } \\
\text { önemlidir. }\end{array}$} & Katilıyorum & 50 & 100,0 & 37 & 97,4 & 87 & 98,9 & & \\
\hline & Katılmıyorum & 0 & 0,0 & 0 & 0,0 & 0 & 0,0 & $\mathrm{~F}$ & 0,432 \\
\hline & Kararsızım & 0 & 0,0 & 1 & 2,6 & 1 & 1,1 & & \\
\hline
\end{tabular}


istatistiksel olarak anlamlı bir ilişki bulunmamakla birlikte, doğum dersi alanların \%100'ü bu önermeye katıldığını ifade etmiştir. Öğrencilerin doğum dersi alma durumları ile "Normal doğumdan sonra cinsel hayat bozulur." önermesi $(\mathrm{p}=0,531)$ arasında istatistiksel olarak anlamlı bir ilişki bulunmamakla birlikte, doğum dersi alanların \%76,3'ü bu önermeye katılmadığını ifade etmiştir. Öğrencilerin doğum dersi alma durumları ile "Sezaryen doğum daha ağrısızdır." önermesi $(\mathrm{p}=0,058)$ arasında istatistiksel olarak anlamlı bir ilişki bulunmamakla birlikte, doğum dersi alanların \%89,5’i bu önermeye katılmadığını ifade etmiştir. Öğrencilerin doğum dersi alma durumları ile "Sezaryen doğum anne ve bebek sağlığı için daha güvenlidir." önermesi $(\mathrm{p}=0,286)$ arasında istatistiksel olarak anlamlı bir ilişki bulunmamakla birlikte, doğum dersi alanların \%94,7’si bu önermeye katılmadığını ifade etmiştir.

\section{TARTISTMA}

Gebelerin doğuma ilişkin doğru bilgilendirilmesi ve doğum şekli tercihlerinin belirlenmesi ebelerin bilgi düzeylerine bağlıdır. ${ }^{[8,14]}$ Ebe olma yolunda ilerleyen ebelik öğrencilerinin doğum dersi almadan önce doğum şekline ilişkin düşüncelerinin toplumdaki bireylerle benzerlik gösterdiği ve doğum dersi aldıktan sonra düşüncelerinin değiştiği bilinmektedir. ${ }^{[25]}$ Çalışmamızda, öğrencilerin doğum dersi alma durumları ile normal vajinal doğum tercihleri arasındaki ilişki incelendiğinde, doğum dersi alanların normal vajinal doğumu daha fazla tercih ettiklerini gördük. Utkualp ve Ogur $^{[27]}$ (2010) hemşirelik öğrencileri ile yaptıkları çalışmada, öğrencilerin \%85,4’ü doğal ve sağlıklı olduğu için normal vajinal doğumu tercih ettiklerini, \%71,8'i doğum ve kadın sağlığı dersini aldıktan sonra doğuma ve kadına olan bakış açılarının olumlu yönde değiştiğini belirtmişlerdir. Kapısız ve ark.'nın ${ }^{[25]}$ (2017) hemşirelik öğrencileri ile yaptığı bir çalışmada, kız öğrenciler stajda karşılaştıkları doğum ile ilgili olumsuz doğum deneyimlerine rağmen, doğumu mucizevi ve mutlaka yaşanması gereken bir deneyim olarak tanımlamışlardır. Öğrencilerin bir kısmı doğum ve kadın sağlı̆̆ı dersi ile birlikte doğum şekli tercihlerinin değiştiğini ve doğuma ilişkin korkularının tetiklendiğini belirtmiştir. Duran ve Atan'ın ${ }^{[1]}$ (2011) ebelik ve hemşirelik öğrencileri ile yaptığı çalışmada ise doğum dersi almış olmanın öğrencilerin doğum şekli tercihlerini etkilemediği saptanmıştır.

Ülkemizde kadınların doğum ile ilgili konularda yeterli bilgiye sahip olmaması, çevredekilerin kötü deneyimlerini paylaşması ve doğumdan/doğum ağrısından korkulması, kadınların normal vajinal doğumu istememelerine sebep olmaktadır. ${ }^{[6,9,25]}$ Çalışmamızda lokal anestezi ile vajinal doğum veya sezaryen ile doğum yapmak isteyen öğrencilerin normal vajinal doğum yapmak istememe nedenleri arasında; doğum korkusunun, doğum ağrısı ile baş edemeyeceği kaygısının, estetik kaygıların ve kontrolünü kaybetme endişesinin tercihlerinde etkili olduğunu gördük. Çakmak ve ark.'nın ${ }^{[20]}$ (2014) çalışmasında kadınlar normal vajinal doğumdan korktukları için sezaryeni tercih ettiklerini ifade etmiştir. Kapısız ve ark.'nın ${ }^{[25]}$ (2017) çalışmasında, öğrencilerin normal vajinal doğum sırasında bebeğin veya kendisinin/eşinin zarar görmesinden, doğum sırasında ağrı/acı duymaktan korktuklar1 bulunmuştur. Duman'ın ${ }^{[28]}$ (2006) yaptığı çalışmada, ilk doğumunu normal vajinal yolla yapanların \%18,4'ü ikinci doğumunu sezaryen ile yapmak istedikleri belirtilmiştir. Çalışmaya katılan kadınlara tercihlerinin nedeni sorulduğunda ise, normal doğumun çok ağrılı olduğunu ve doğumda kan kaybının fazla olduğunu belirtmişlerdir. Ergöl ve Kürtüncü’nün ${ }^{[2]}$ (2014) yaptığı çalışmada, kadınların çoğunluğu $(\% 47,4)$ doğumdan korkmaları nedeniyle sezaryen ile doğum yapmayı tercih ettiklerini ifade etmişlerdir. Benzer olarak, Gözükara ve Eroğlu'nun ${ }^{[26]}$ (2008) yaptığı çalışmada da kadınların sezaryen doğumu tercih etme nedenleri arasında en fazla doğumdan/doğum ağrısından korkma $(\% 71,1)$ ve bebek için daha sağlıklı olduğunu düşünme $(\% 15,5)$ yer almıştır. Literatür incelendiğinde, kadınların doğum korkusu yaşadıkları ve bu nedenle sezaryeni tercih ettikleri görülmüştür. Kadınlar normal vajinal doğumun yararları hakkında bilgilendirilmeli ve normal vajinal doğum yapmaları konusunda cesaretlendirilmelidir.

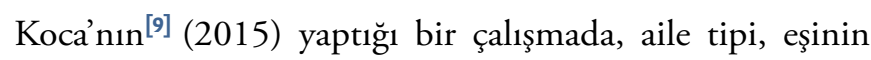
eğitim düzeyi, yaşanılan yer ve sosyal güvence durumlarının kadınların doğum şekli tercihlerini etkilemediği bulunmuştur. Vatansever ve Okumuş ${ }^{[6]}$ (2013) çalışmalarında, gebelerin sosyo-demografik verileri ile doğum şekli kararları arasındaki ilişkiyi incelemiş, doğum şekli kararının yaş, eğitim durumu ve çalışma durumuna göre farklılık gösterdiğini, fakat ekonomik durum ve sağlık güvencesine göre farklılık göstermediğini saptamışlardır. Elkin'in ${ }^{[8]}$ (2015) yaptığı çalışmada, kadınların doğum şekli ile eğitim durumları, yaşadıkları yer, çalışma durumu, aylık gelir durumu ve gebelikle ilgili sorun yaşama durumu karşıllaştırıldığında, istatistiksel olarak anlamlı bir ilişki bulunmuştur. İlköğretim mezunu olanlarda normal doğum daha yaygınken, üniversite mezunu olanlar sezaryenle doğumu daha fazla tercih etmişlerdir. Aynı çalışmada, ilçede yaşayanların normal doğumu daha fazla tercih ettikleri ve ekonomik durumun yükselmesiyle birlikte sezaryen tercih oranlarının yükseldiği de görülmüştür. Literatür incelendiğinde, ekonomik durum ve eğitim seviyesi arttıkça sezaryenle doğum yapma isteğinin arttığı sonucuna ulaşılmıştır. 
Çalışmamızda, öğrencilerin "Normal doğum doğal bir süreçtir.", "Sezaryen doğumun komplikasyonları daha fazladır.", "Normal doğumdan sonra kadınlar kendini daha çabuk toparlar.", "Normal doğumdan sonra anne-bebek etkileşimi erken dönemde başlar." ve "Doğum öncesi destek ve bilgilendirme kadınların doğum şekli tercihinde etkili ve önemlidir." görüşlerine katıldıkları görüldü. Öğrenciler "Normal doğumdan sonra cinsel hayat bozulur." ve "Sezaryen doğum daha ağrısızdır." görüşlerine ise katılmadılar. Koca'nın ${ }^{[0]}$ (2015) yaptığı bir çalışmada, gebeler normal vajinal doğumdan sonra daha çabuk iyileşme olacağı ve doğum sonu dönemin daha az ağrılı olacağı gibi görüşlere katıldıklarını ifade etmişlerdir. Duman'ın $^{[28]}$ (2006) yaptığı çalışmada, normal vajinal doğumu tercih eden sağlık çalışanları, normal doğumun doğal ve fizyolojik bir süreç olduğunu, günlük aktivitelere çabuk dönüldüğünü, bebeklerini hemen emzirebildiklerini belirtirken, sezaryen ile doğumu seçenler bebeğin daha az zarar gördüğünü düşündüklerini belirtmişlerdir. Duran ve Altan'ın ${ }^{[1]}$ (2011) çalışmasında, kadınların çoğunun normal doğumun anne ve bebek sağlı̆̆ı için daha iyi olacağını düşündükleri belirtilmiş, kadınlar normal doğumu doğal bir süreç olarak tanımlamışlardır. Normal vajinal doğumu tercih eden kadınlar, doğumdan sonra daha çabuk ayağa kalktıkları için normal doğumun daha sağlıklı olduğunu belirtirken, sezaryen ile doğumu tercih edenler ise sezaryen doğumun anne ve bebek sağllı̆̆ için daha güvenli olduğunu ifade etmişlerdir. Memiş' in ${ }^{[5]}$ (2016) yaptığı çalışmada, kadınların çoğunun normal vajinal doğum yaptıktan sonra cinsel yaşamlarının bozulacağını düşündüklerini ifade etmiştir. Çubuk'un ${ }^{[21]}$ (2014) çalışmasında, sezaryen ile doğumu tercih eden gebeler sezaryenin bebek için daha sağlıklı olduğunu belirtmişlerdir. Oktay'ın ${ }^{[18]}$ (2012) yaptığı çalışmada ise kadınların bir kısmı doğum öncesi bilgilendirmenin doğum şekli üzerinde etkili olduğunu ve ilk doğumun diğer doğumları etkilediğini ifade etmiştir. Literatür incelendiğinde, toplumun normal vajinal doğuma ilişkin bilgilerinin yetersiz olduğu görülmüştür. Doğum öncesi destek ve bilgilendirme ile çiftlerin doğru karar vermeleri sağlanmalıdır.

\section{SONUC}

Ülkemizde yapılan çalışmalar, kadınların doğuma ilişkin bilgi düzeylerinin yetersiz olduğunu ve doğumdan/doğum ağrısından korktukları için sezaryeni tercih ettiklerini göstermiştir. Birinci basamakta özel bir yere sahip olan ebeler, nitelikli bir antenatal takip ile çiftleri doğuma hazırlamakta ve yürüttükleri danışmanlık hizmetleri ile çiftlerin doğum şekli tercihlerini etkilemektedirler. Bu nedenle, geleceğin sağlık profesyonelleri olan ebelik öğrencilerinin normal vajinal doğum konusunda yeterli ve doğru bilgiye sahip olmaları, toplumda insanların normal vajinal doğuma olan bakış açılarının değişmesinde önemli yer tutmaktadır. Çalışmamızda, öğrencilerin çoğunluğu doğumun normal bir süreç olduğunu, daha sağlıklı olduğu için normal vajinal doğumu tercih ettiklerini ve doğum dersinin tercihlerinde etkili olduğunu ifade etmiştir. Öğrencilerin normal vajinal doğum konusunda olumlu bir tutum geliştirebilmesi için doğum şekli konusundaki bilgi eksiklikleri tanımlanmalı, giderilmeli ve karar verme becerileri güçlendirilmelidir. Ayrıca, müfredatta verilen doğum dersine ek olarak; doğum şekline ilişkin eğitimlerin yapılması, öğrencilerin duygu ve düşüncelerini ifade etmelerine firsat tanınması ve okul-hastane iş birliğinin sağlanması önerilebilir.

\section{Sunum}

Bu araştırma, 03-05 Mayıs 2018 tarihleri arasında Amasya'da düzenlenecek olan 5.

Uluslararası \& 9. Ulusal Ebelik Öğrencileri Kongresi'nde sözel bildiri olarak sunulacaktır.

\section{Hakem Değerlendirmesi}

Dış bağımsız

Çıkar Çatışması

Yazarlar çıkar ilişkisi olmadığını beyan etmişlerdir.

Finansal Destek

Herhangi bir mali destek alınmamıştır.

\section{Peer-review}

Externally peer-reviewed.

Conflict of Interest

No conflict of interest was declared by the authors.

Financial Disclosure

No financial disclosure was received.

\section{KAYNAKLAR}

1. Taşçı Duran E, Ünsal Atan Ş. Kadınların sezaryen/vajinal doğuma bakış açılarının kalitatif analizi. Genel Tıp Derg 2011;21:83-8.

2. Ergöl Ş, Kürtüncü M. Bir üniversite hastanesinde kadınların sezaryen doğum tercihlerini etkileyen faktörler. Hacettepe Üniversitesi Hemşirelik Fakültesi Dergisi 2014;26-34.

3. Karabulutlu Ö. Kadınların doğum şekli tercihlerini etkileyen faktörler. İ. Ü. F. N. Hem Derg 2012;20:210-8.

4. Bülbül T, Özen B, Çopur A, Kayacık F. Gebelerin doğum korkusu ve doğum şekline karar verme durumlarının incelenmesi. Sağlık Bilimleri Dergisi 2016;25:126-30.

5. Memiş Ö. Sağlık çalışanları tarafından tercih edilen doğum yapma yöntemlerinin belirlenmesi. Üsküdar Üniversitesi: Sağlık Bilimleri Enstitüsü, Hastane İşletmeciliği Anabilim Dalı, Yüksek Lisans Tezi. İstanbul: 2016.

6. Vatansever Z, Okumuş H. Gebelerin doğum şekline karar verme durumlarının incelenmesi. DEUHYO ED Dokuz Eylül Üniversitesi, Hemşirelik Yüksekokulu Elektronik Dergisi 2013;6:81-7.

7. Belkız L. Doğum şeklinin anne bebek bağı üzerine etkisinin incelenmesi. Haliç Üniversitesi, Sağlık Bilimleri Enstitüsü, Yüksek Lisans Tezi. İstanbul: 2017.

8. Elkin N. Bir aile sağlığı merkezine başvurmuş olan 18-49 yaş arası kadınların doğum şekli tercihleri ve ilişkili faktörler. Anadolu Klin 2016;21:119-28.

9. Çoban Koca S. Kadınların sezaryen doğum tercihi ve etkileyen faktörler. Cumhuriyet Üniversitesi: Sağlık Bilimleri Enstitüsü, Yüksek Lisans Tezi. Sivas: 2015. 
10. Mazzoni A, Althabe F, Liu NH, Bonotti AM, Gibbons L, Sanchez AJ, Belizán JM. Women's preference for caesarean section: a systematic review and meta-analysis of observational studies. BJOG 2011;118:391-9. [CrossRef]

11. Souza JP, Gülmezoglu A, Lumbiganon P, Laopaiboon M, Carroli $\mathrm{M}$, Fawoll B, et al. Caesarean section without medical indications is associated with an increased risk of adverse short-term maternal outcomes: the 2004-2008 WHO Global Survey on Maternal and Perinatal Health. BMC Med 2010;8:71. [CrossRef]

12. Carrapato MRG, Ferreira AM, Wataganara T. Cesarean section: the pediatricians' views. J Matern Fetal Neonatal Med 2017;30:2081-5. [CrossRef]

13. Karakuş A. Sezaryen ve normal doğum yapan kadınların doğum yöntemlerine olan davranış ve tutumlarının belirlenmesi. İstanbul Üniversitesi: Sağlık Bilimleri Enstitüsü, Basılmamış Yüksek Lisans Tezi. İstanbul: 2007.

14. Serçekuş P, Egelioğlu Çetişli N, İnci FH. Türkiye'deki nullipar kadınlar ve eşlerinin doğum tercihleri. Cinsel Sağlık ve Üreme Sağlığı Derg 2015;6:182-5.

15. Uzunçakmak C, Güldaş A, Aydın S, Var A, Özçam H. S.B. İstanbul Eğitim Araştırma Hastanesi Kadın Hastalıkları ve Doğum Kliniği'nde 2005-2012 yılları arasında sezaryen ile doğum yapan hastaların değerlendirilmesi. İstanbul Tip Derg 2013;14:112-6. [CrossRef]

16. Yıldız Ş, Caypınar SS, Cengiz H, Dağdeviren H, Kanawati A. Türk kadınlarının doğum yöntemleri hakkındaki bilgi düzeyi ve bakış açısı. JCEI 2014;5:173-8.

17. İlhan G, Atmaca FFV, Eken M, Tavukçuoğlu Z, Özel A, Özdemir M, Güngör ES. What is Turkish women's opinion about vaginal delivery? Turk J Obstet Gynecol 2015;2:75-8. [CrossRef]

18. Oktay S. Doğum yapan kadınların doğum şekline yönelik tercihleri ve etkileyen faktörler. Cumhuriyet Üniversitesi: Sağlık Bilimleri Enstitüsü, Yüksek Lisans Tezi. Sivas: 2012.
19. Amanak K, Akdolun Balkaya N. Ebelik bölümü öğrencilerinin doğal doğuma yönelik bilgi ve düşünceleri. Gümüşhane Üniversitesi Sağlık Bilimleri Dergisi 2013;2:169-92.

20. Çakmak B, Arslan S, Nacar MC. Kadınların isteğe bağlı sezaryen konusundaki görüşleri. Fırat Tip Derg 2014;19:122-5.

21. Çubuk MM. Kadınların doğum tercihleri üzerine sağlık eğitiminin etkisi. İnönü Üniversitesi: Sağlık Bilimleri Enstitüsü, Yüksek Lisans Tezi. Malatya: 2014.

22. Akçay AE. Kayseri doğumevi hastanesine başvuran gebelerin doğum öncesi bakım alma durumunun doğum tercihine ve doğum tercihlerine etkisi. Erciyes Üniversitesi: Tip Fakültesi, Yüksek Lisans Tezi. Kayseri: 2012.

23. Beirvand PS, Moghadam ZB, Salsali M, Majd HA, Birjandi M, Khalesi ZB. Prevalence of Fear of Childbirth and its Associated Factors in Primigravid Women: A Cross- Sectional Study. Shiraz E Med J 2017;18:e61896. [CrossRef]

24. Bozkurt Ş. Normal doğumda ve sezaryen doğumda anne memnuniyetinin değerlendirilmesi. İstanbul Üniversitesi: Sağllk Bilimleri Enstitüsü, Yüksek Lisans Tezi. İstanbul: 2013.

25. Kapısız Ö, Karaca A, Süzer Özkan F, Gülen Savaş H. Hemşirelik öğrencilerinin doğum algısı. Düzce Üniversitesi Sağlık Bilimleri Enstitüsü Dergisi 2017;7:156-60.

26. Gözükara F, Eroğlu K. İlk doğumunu yapmış kadınların (primipar) doğum şekline yönelik tercihlerini etkileyen faktörler. Hacettepe Üniversitesi Sağlık Bilimleri Fakültesi Hemşirelik Dergisi 2008;32-46.

27. Utkualp N, Ogur P. Öğrencilerin doğum kadın hastalıkları ve hemşireliği dersi alan uygulamasına ilişkin duygu ve düşünceleri. Maltepe Üniversitesi Hemşirelik Bilim ve Sanatı Dergisi 2010;3(1).

28. Duman Z. Sağlık çalışanlarının normal doğum ve sezaryen ile ilgili düşünceleri. Afyon Kocatepe Üniversitesi: Sağlık Bilimleri Enstitüsü, Yüksek Lisans Tezi. Afyonkarahisar: 2006. 